\title{
Comparison of plasmid-mediated quinolone resistance and extended-spectrum $\beta$-lactamases in third-generation cephalosporin-resistant Enterobacteriaceae from four Irish hospitals
}

\author{
Correspondence \\ Fiona Walsh \\ fiona.walsh@acw.admin.ch or \\ fiona1walsh@gmail.com
}

Received 14 June 2011

Accepted 6 September 2011

\author{
Fiona Walsht and Thomas R. Rogers \\ Department of Clinical Microbiology, Sir Patrick Dun Laboratory, University of Dublin, \\ Trinity College, St James's Hospital Campus, Dublin 8, Ireland
}

\begin{abstract}
In this study, the frequency of extended-spectrum $\beta$-lactamases (ESBL) and plasmid-mediated quinolone resistance (PMQR) mechanisms were investigated in 206 clinical isolates of thirdgeneration cephalosporin (3GC)-resistant Enterobacteriaceae in four hospitals in the Republic of Ireland. bla $\mathrm{C}_{\mathrm{CTX}-\mathrm{M}-15}$ was the predominant $\mathrm{ESBL}$ gene. Of these $3 \mathrm{GC}$ resistant isolates, $54 \%$ were also resistant to ciprofloxacin. Investigation of the PMQR mechanisms revealed that the aac $\left(6^{\prime}\right)$ $\mathrm{lb}$-cr gene predominated in fluoroquinolone-resistant (FOR) strains of Escherichia coli and Klebsiella pneumoniae, while the qnrA gene predominated in the FOR strains of Enterobacter. The bla $\mathrm{CTX}-\mathrm{M}-15$ gene was frequently identified with the aac $\left(6^{\prime}\right) / b$-cr gene but was not always on the same plasmid. The prevalence of the b/a $a_{\mathrm{CTX}-\mathrm{M}-15}$ gene appeared to be hospital-dependent. The epidemiology of both ESBL-producing and PMQR strains within the four hospitals indicated that their prevalence is not due to the spread of these resistance genes between isolates from different hospitals.
\end{abstract}

\section{INTRODUCTION}

Since the first description of extended-spectrum $\beta$-lactamases (ESBLs) in 1983, incidences of ESBL-producing bacterial strains have been reported increasingly worldwide (Cantón et al., 2008). In Europe there has been a transition from the dominance of the $b l a_{\mathrm{TEM}}$ and $b l a_{\mathrm{SHV}}$ genes towards a greater prevalence of $b l a_{\mathrm{CTX}-\mathrm{M}}$ genes in ESBL-producing members of the family Enterobacteriaceae (Bonnet, 2004). These multi-drug resistance genes are frequently located on plasmids. Associations between CTX-M-type ESBLs and resistance to other antimicrobial agents have been identified in surveys from many countries including Canada, Greece, the UK and Italy. The fluoroquinolone (FQ) resistance genes $q n r$ and $a a c\left(6^{\prime}\right) I b-c r$ have been frequently associated with $\beta$-lactamase-mediated resistance, conferred by $b l a_{\mathrm{TEM}}$, bla $a_{\mathrm{SHV}}$ and bla $a_{\mathrm{CTX}-\mathrm{M}}$ genes (Boyd et al., 2004; Woodford et al., 2009). The dissemination of these ESBL genes and plasmid-mediated quinolone resistance (PMQR) is making

tPresent address: Department of Bacteriology, Federal Department of Economic Affairs (FDEA), Forschungsanstalt Agroscope ChanginsWädenswil (ACW), Postfach, 8820 Wädenswil, Switzerland.

Abbreviations: 3GC, third-generation cephalosporin; ESBL, extendedspectrum $\beta$-lactamase; FQ, fluoroquinolone; FQR, fluoroquinoloneresistant; MDR, multi-drug resistant; PMOR, plasmid-mediated quinolone resistance.

The GenBank/EMBL/DDBJ accession number for the aac $\left(6^{\prime}\right) / b$-cr partial gene sequence of Enterobacter aerogenes is EU081298.1. it increasingly difficult to manage infections caused by multi-drug resistant (MDR) strains of Enterobacteriaceae.

There have been relatively limited data published on MDR Enterobacteriaceae isolates from the Republic of Ireland. As part of the data collected for the European Antibiotic Resistance Surveillance Network (EARS-Net, 2010), the rates of third-generation cephalosporin (3GC) and FQ resistance in invasive Escherichia coli isolates reported from the ROI in 2009 were $6.5 \%$ and $21.7 \%$, respectively, while the rates of $3 \mathrm{GC}$ and $\mathrm{FQ}$ resistance in Klebsiella pneumoniae isolates were $11.1 \%$ and $10.8 \%$, respectively. The proportions of 3GC-resistant E. coli and K. pneumoniae in which ESBL production was also detected were $85.5 \%$ and $78.1 \%$, respectively. The aims of the present study were to identify the mechanisms of plasmidmediated resistance to 3GCs and FQs in MDR Enterobacteriaceae isolates collected from four Irish hospitals, characterize the plasmids harbouring the $a a c\left(6^{\prime}\right) I b$-cr gene, and investigate the ability of these plasmids to enhance the development of ciprofloxacin resistance in Escherichia coli.

\section{METHODS}

Bacterial strains. Clinical isolates of E. coli, K. pneumoniae and Enterobacter were collected from a 900-bed tertiary referral university hospital in the Republic of Ireland between July 2006 and June 2008 (CLSI, 2007). The bacteria, which were collected from all sites of 
infection by the diagnostic microbiology laboratory, were screened for resistance to 3GCs cefotaxime and/or ceftazidime using in vitro antibiotic susceptibility testing according to CLSI guidelines, except for isolates of E. coli collected from urinary samples, which were not screened for 3GC resistance. Additionally, 3GC- and FQ-resistant isolates were collected from three other Irish hospitals during the same period and added to the main collection. The total numbers of isolates of E. coli, K. pneumoniae and Enterobacter collected were 73, 56 and 77 , respectively.

PCR detection of resistance genes. All isolates were screened for the presence of $b l a_{\mathrm{TEM}}, b l a_{\mathrm{SHV}}, b l a_{\mathrm{OXA}}$ and $b l a_{\mathrm{CTX}-\mathrm{M}}$ genes by using multiplex PCR (Colom et al., 2003; Woodford et al., 2006). PCRpositive isolates were confirmed by individual PCRs and the purified products were sequenced in the forward and reverse directions using the amplification primers or the primers $b a_{\mathrm{TEM}}$ forward $5^{\prime}$-AGATCAGTTGGGTGCACGAG-3' and bla $a_{\text {TEM }}$ reverse $5^{\prime}$-CTTGGTCTGACAGTTACC-3' for the $b{ }^{\prime} a_{\text {TEM }}$ PCR positives. All isolates, regardless of their susceptibility to FQ, were analysed for the $a a c\left(6^{\prime}\right) I b$-cr gene by using PCR, and for qnrA, qnrB and qnrS genes by using multiplex PCR (Robicsek et al., 2006; Gay et al., 2006). PCR-positive isolates were confirmed by individual PCR and subsequent sequencing in the forward and reverse directions.

Plasmid transformation and profiles. All aac $\left(6^{\prime}\right) I b-c r$-positive isolates were selected for plasmid analysis. Plasmid extractions were performed using a Qiagen Plasmid Midi kit. Extracted plasmids were transformed into TOP10 competent E. coli cells by electroporation and the cells were spread on Mueller-Hinton agar containing ampicillin, cefotaxime or kanamycin $\left(20 \mathrm{mg}^{-1}\right.$ each). All resulting transformant colonies were screened both for the presence of the $a a c\left(6^{\prime}\right) I b-c r$ gene and all of the additional plasmid-mediated ESBL genes which were present in the parent clinical isolate. Plasmids were extracted from PCR-positive transformants and E. coli NCTC 13400 (pEK499) cells using the Qiagen Plasmid Midi kit. The extracted plasmids were digested using restriction enzyme PstI and separated on $0.8 \%$ agarose gels at $100 \mathrm{~V}$ for 5 min followed by $75 \mathrm{~V}$ for $2 \mathrm{~h}$. The resulting banding patterns were analysed using BioNumerics software in order to determine the percentage similarity between the plasmids.

Mutation studies. Transformants and competent cells were individually inoculated into $\mathrm{LB}$ broth and incubated at $37^{\circ} \mathrm{C}$ overnight. A $100 \mu \mathrm{l}$ volume of each of the overnight cultures was spread on to Mueller-Hinton agar plates containing ciprofloxacin at concentrations equal to the MIC or $2 \times$ MIC for that strain (Walsh et al., 2003). Plates with each drug concentration, together with a control with no antibiotic, were inoculated in triplicate and incubated at $37{ }^{\circ} \mathrm{C}$ for $48 \mathrm{~h}$. The mutants generated were purified by subculturing twice on plates with the selective ciprofloxacin concentration. The MIC of ciprofloxacin for each of the mutants was determined according to the CLSI guidelines (CLSI, 2007). Successive generations of mutants were derived in the same way as the first generation. This process was repeated using increasingly higher concentrations of ciprofloxacin until high-level resistance was achieved (MIC $\geqslant 8 \mathrm{mg} \mathrm{l}^{-1}$ ) or the MICs for successive generations remained constant over two successive generations.

\section{RESULTS AND DISCUSSION}

\section{Antibiotic resistance profiles}

The prevalence and range of multi-drug resistance in the 206 3GC-resistant isolates are shown in Table 1. The majority of isolates were collected from hospital 4 . Within the 3GCresistant populations from the four hospitals, $41 \%$ of the $E$. coli, $45 \%$ of the K. pneumoniae and $5 \%$ of the Enterobacter isolates were ESBL-positive. Few strains of K. pneumoniae or E. coli were resistant to imipenem but almost one third of the Enterobacter isolates were imipenem resistant, all of which were isolated from hospital 4. There were significantly higher levels of amikacin resistance in isolates of $K$. pneumoniae and E. coli when compared to another Irish

Table 1. Prevalence of MDR isolates collected from four Irish hospitals

AMC, amoxicillin + clavulanic acid; CTX, cefotaxime; CAZ, ceftazidime; TZP, piperacillin-tazobactam; CIP, ciprofloxacin; LEVO, levofloxacin, AK, amikacin; GM, gentamicin; IMI, imipenem.

\begin{tabular}{|c|c|c|c|c|c|c|c|c|c|c|c|}
\hline \multirow[t]{2}{*}{ Taxon/source } & \multirow{2}{*}{$\begin{array}{c}\text { Resistant to } \\
\text { 3GC }\end{array}$} & \multirow{2}{*}{$\begin{array}{l}\text { Positive for } \\
\text { ESBL by PCR }\end{array}$} & \multicolumn{9}{|c|}{ Resistant to: } \\
\hline & & & AMC & CTX & CAZ & TZP & CIP & LEVO & $\mathrm{AK}$ & GM & IMI \\
\hline Enterobacter & 77 & 4 & 73 & 73 & 73 & 68 & 30 & 41 & 1 & 29 & 23 \\
\hline Hospital 1 & 5 & 0 & 5 & 5 & 5 & 1 & 4 & 3 & 0 & 0 & 0 \\
\hline Hospital 2 & 11 & 0 & 10 & 10 & 10 & 7 & 11 & 9 & 0 & 0 & 0 \\
\hline Hospital 3 & 3 & 0 & 3 & 2 & 2 & 1 & 3 & 2 & 0 & 0 & 0 \\
\hline Hospital 4 & 58 & 4 & 55 & 56 & 56 & 59 & 12 & 27 & 1 & 29 & 23 \\
\hline K. pneumoniae & 56 & 25 & 51 & 51 & 49 & 44 & 39 & 37 & 8 & 16 & 7 \\
\hline Hospital 1 & 2 & 1 & 2 & 2 & 2 & 0 & 2 & 1 & 0 & 0 & 0 \\
\hline Hospital 2 & 7 & 3 & 6 & 7 & 7 & 3 & 7 & 6 & 0 & 0 & 0 \\
\hline Hospital 3 & 11 & 10 & 9 & 11 & 11 & 4 & 11 & 11 & 0 & 0 & 0 \\
\hline Hospital 4 & 36 & 11 & 34 & 31 & 29 & 37 & 19 & 19 & 8 & 16 & 7 \\
\hline E. coli & 73 & 30 & 72 & 73 & 59 & 59 & 42 & 41 & 23 & 32 & 4 \\
\hline Hospital 1 & 3 & 1 & 2 & 3 & 2 & 2 & 3 & 3 & 0 & 0 & 0 \\
\hline Hospital 2 & 11 & 3 & 8 & 11 & 6 & 6 & 11 & 11 & 0 & 0 & 0 \\
\hline Hospital 3 & 15 & 13 & 14 & 15 & 8 & 8 & 15 & 14 & 0 & 0 & 0 \\
\hline Hospital 4 & 44 & 13 & 48 & 44 & 43 & 43 & 13 & 13 & 23 & 32 & 4 \\
\hline
\end{tabular}


Table 2. Distribution of ESBL and PMOR genes among 206 MDR Enterobacteriaceae isolates collected from 4 Irish hospitals

Taxa: 1, E. coli; 2, K. pneumoniae; 3, Enterobacter. Values represent number of isolates containing bla genes, conferring $\beta$-lactam resistance, $a a c\left(6^{\prime}\right) I b-c r$ or $q n r$ genes, conferring FQ resistance, or a mixture of these genes.

\begin{tabular}{|c|c|c|c|}
\hline Resistance element & 1 & 2 & 3 \\
\hline \multicolumn{4}{|l|}{ Hospital 1} \\
\hline$b l a_{\mathrm{TEM}-1}$ & & 1 & \\
\hline$b l a_{\mathrm{TEM}-170}$ & 1 & & \\
\hline$b l a_{\mathrm{SHV}-11}$ & & 1 & \\
\hline$b l a_{\mathrm{OXA}-1}$ & 1 & 1 & 2 \\
\hline$b l a_{\mathrm{CTX}-\mathrm{M}-2}$ & 1 & & \\
\hline$a a c\left(6^{\prime}\right) I b-c r$ & 1 & 1 & \\
\hline$q n r A$ & & 1 & \\
\hline $\begin{array}{l}b l a_{\mathrm{TEM}-1}+b l a_{\mathrm{SHV}-11}+b l a_{\mathrm{OXA}} \\
\quad+q n r A+a a c\left(6^{\prime}\right) I b-c r\end{array}$ & & 1 & \\
\hline $\begin{array}{l}b l a_{\mathrm{OXA}}+b l a_{\mathrm{TEM}-170} \\
\quad+b l a_{\mathrm{CTX}-\mathrm{M}-2}+a a c\left(6^{\prime}\right) I b-c r\end{array}$ & 1 & & \\
\hline \multicolumn{4}{|l|}{ Hospital 2} \\
\hline$b l a_{\mathrm{TEM}-1}$ & 7 & 2 & 3 \\
\hline$b l a_{\text {TEM-171 }}$ & 1 & & \\
\hline$b l a_{\text {TEM-172 }}$ & 1 & & \\
\hline$b l a_{\mathrm{SHV}-11}$ & & 1 & 2 \\
\hline$b l a_{\mathrm{SHV}-12}$ & & & 1 \\
\hline$b l a_{\mathrm{SHV}-28}$ & & 1 & \\
\hline$b l a_{\mathrm{SHV}-123}$ & & 1 & \\
\hline$b l a_{\mathrm{SHV}-124}$ & & 1 & \\
\hline$b l a_{\mathrm{SHV}-126}$ & & & 1 \\
\hline$b l a_{\mathrm{OXA}-1}$ & 4 & 1 & 1 \\
\hline$b l a_{\mathrm{CTX}-\mathrm{M}-15}$ & 3 & & \\
\hline$b l_{\mathrm{CTX}-\mathrm{M}-25}$ & & 1 & \\
\hline$a a c\left(6^{\prime}\right) I b-c r$ & 2 & & \\
\hline$q n r A$ & & & 1 \\
\hline$q n r B$ & & 1 & 1 \\
\hline$q n r A+q n r B$ & & & 1 \\
\hline $\begin{array}{l}b l a_{\mathrm{CTX}-\mathrm{M}-15}+b l a_{\mathrm{OXA}} \\
+a a c\left(6^{\prime}\right) I b-c r\end{array}$ & 1 & & \\
\hline $\begin{array}{l}b l a_{\mathrm{TEM}-1}+b l a_{\mathrm{SHV}-11}+b l a_{\mathrm{OXA}} \\
\quad+a a c\left(6^{\prime}\right) I b-c r\end{array}$ & & 1 & \\
\hline$q n r A+b l a_{\mathrm{SHV}-12}$ & & & 1 \\
\hline$q n r A+q n r B+b l a_{\mathrm{SHV}-126}$ & & & 1 \\
\hline$q n r B+b l a_{\mathrm{SHV}-124}$ & & 1 & \\
\hline \multicolumn{4}{|l|}{ Hospital 3} \\
\hline$b l a_{\mathrm{TEM}-1}$ & 8 & 4 & 1 \\
\hline$b l a_{\mathrm{TEM}-40}$ & 1 & & \\
\hline$b l a_{\mathrm{TEM}-173}$ & 1 & & \\
\hline$b l a_{\mathrm{OXA}-1}$ & 7 & 7 & \\
\hline$b l a_{\mathrm{CTX}-\mathrm{M}-15}$ & 13 & 9 & \\
\hline$a a c\left(6^{\prime}\right) I b-c r$ & 7 & 6 & \\
\hline$q n r S$ & & 1 & \\
\hline $\begin{array}{l}b l a_{\mathrm{TEM}-1}+b l a_{\mathrm{CTX}-\mathrm{M}-15}+b l a_{\mathrm{OXA}} \\
\quad+a a c\left(6^{\prime}\right) I b-c r\end{array}$ & 4 & 3 & \\
\hline $\begin{array}{l}b l a_{\mathrm{CTX}-\mathrm{M}-15}+b l a_{\mathrm{OXA}} \\
+a a c\left(6^{\prime}\right) I b-c r\end{array}$ & 2 & 3 & \\
\hline$b l a_{\mathrm{OXA}}+a a c\left(6^{\prime}\right) I b-c r$ & 1 & & \\
\hline
\end{tabular}

Table 2. cont.

\begin{tabular}{|c|c|c|c|}
\hline Resistance element & 1 & 2 & 3 \\
\hline \multicolumn{4}{|l|}{ Hospital 4} \\
\hline$b l a_{\mathrm{TEM}-1}$ & 21 & 12 & 8 \\
\hline$b l a_{\mathrm{TEM}-30}$ & 1 & & \\
\hline$b l a_{\mathrm{TEM}-174}$ & 1 & & \\
\hline$b l a_{\mathrm{SHV}-11}$ & & 1 & \\
\hline$b l a_{\mathrm{SHV}-12}$ & & & 2 \\
\hline$b l a_{\mathrm{SHV}-125}$ & & 1 & \\
\hline$b l a_{\mathrm{SHV}-127}$ & & 1 & \\
\hline$b l a_{\mathrm{OXA}-1}$ & 18 & 8 & 11 \\
\hline$b l a_{\mathrm{CTX}-\mathrm{M}-2}$ & 1 & 1 & \\
\hline$b l a_{\mathrm{CTX}-\mathrm{M}-15}$ & 5 & 8 & 1 \\
\hline$b l a_{\mathrm{CTX}-\mathrm{M}-25}$ & & 1 & \\
\hline$a a c\left(6^{\prime}\right) I b-c r$ & 3 & 3 & 2 \\
\hline$q n r A$ & 1 & & 7 \\
\hline$q n r B$ & & 2 & \\
\hline$q n r S$ & & & 1 \\
\hline $\begin{array}{l}b l a_{\mathrm{TEM}-1}+b l a_{\mathrm{CTX}-\mathrm{M}-15}+b l a_{\mathrm{OXA}} \\
\quad+a a c\left(6^{\prime}\right) I b-c r\end{array}$ & 1 & 1 & \\
\hline $\begin{array}{l}b l a_{\mathrm{CTX}-\mathrm{M}-15}+b l a_{\mathrm{OXA}} \\
+a a c\left(6^{\prime}\right) I b-c r\end{array}$ & 2 & & \\
\hline$b l a_{\mathrm{OXA}}+a a c\left(6^{\prime}\right) I b-c r$ & & & \\
\hline$q n r A+b l a_{\mathrm{SHV}-12}$ & 1 & 1 & 2 \\
\hline$q n r A+b l a_{\mathrm{TEM}-1}$ & & & 1 \\
\hline$q n r A+b l a_{\mathrm{OXA}-1}$ & & & 2 \\
\hline$q n r B+b l a_{\mathrm{SHV}-11}$ & & 1 & 3 \\
\hline$q n r B+b l a_{\mathrm{SHV}-125}+b l a_{\mathrm{CTX}-\mathrm{M}-15}$ & & 1 & \\
\hline
\end{tabular}

collection, where only one amikacin-resistant isolate was described among $66 \mathrm{MDR}$ strains of Enterobacteriaceae (Mac Aogáin et al., 2010). Aminoglycoside-resistant isolates were also only detected in hospital 4 . The proportions of ciprofloxacin- and levofloxacin-resistant strains within the 3GC-resistant populations were, respectively, 58 and $56 \%$ in E. coli, 70 and $66 \%$ in K. pneumoniae and 39 and $53 \%$ in species of Enterobacter. Almost all of the 3GC-resistant isolates from hospitals 1, 2 and 3 were FQ resistant; however, $\leqslant 50 \%$ of the isolates from hospital 4 were resistant to FQs.

\section{Third-generation cephalosporin resistance mechanisms}

In strains of E. coli and K. pneumoniae, the predominant ESBL gene was bla $a_{\mathrm{CTX}-\mathrm{M}-15}$. This has also been reported as the most common ESBL gene in another Irish survey of 25 MDR E. coli isolates (Mac Aogáin et al., 2010). The distribution of the $b l a_{\mathrm{CTX}-\mathrm{M}}$ genes was hospital dependent, as shown in Table 2. Hospital 3 contained $22 b l a_{\mathrm{CTX}-\mathrm{M}-15^{-}}$ positive isolates, while the isolates from hospital 4 contained the largest variety of $b l a_{\mathrm{CTX}-\mathrm{M}}$ genes, including $b l a_{\mathrm{CTX}-\mathrm{M}-2}$, $b l a_{\mathrm{CTX}-\mathrm{M}-15}$ and $b l a_{\mathrm{CTX}-\mathrm{M}-25}$. The $b l a_{\mathrm{CTX}-\mathrm{M}-25}$ gene encodes a rare ESBL that was first associated with an outbreak in Canada (Munday et al., 2004). Our collection contained one

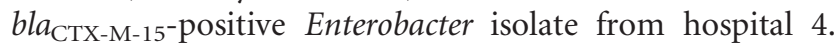
Few $b l a_{\text {TEM }}$ and $b l a_{\text {SHV }}$ ESBL genes were detected. However, 

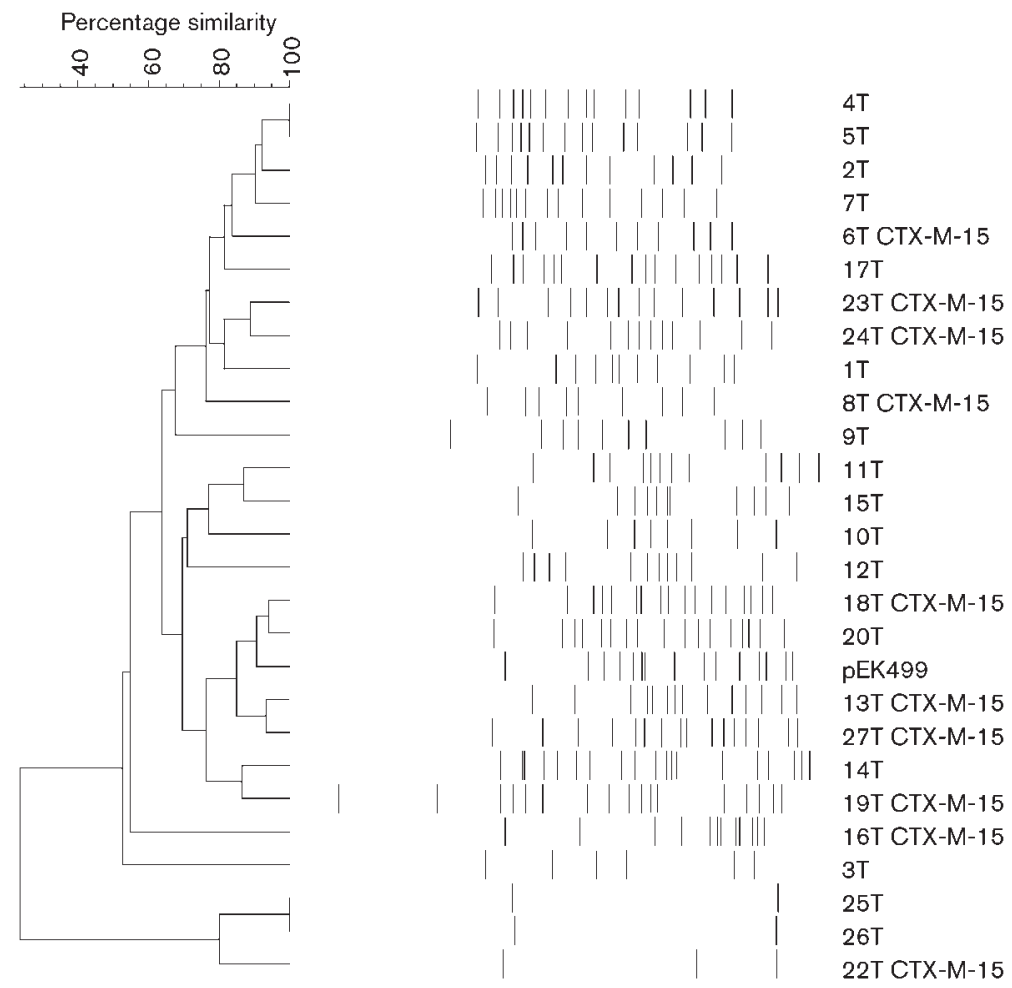

\begin{abstract}
Fig. 1. Comparison of banding patterns of Pstl-digested plasmids from transformants and pEK499 from E. coli NCTC 13400 with a dendrogram showing percentage similarity between banding patterns. CTX-M-15 indicates that this plasmid contains a b/a gene.
\end{abstract}

in all three populations from each hospital, the predominant $\beta$-lactamase genes were $b l a_{\mathrm{TEM}-1}$ and $b l a_{\mathrm{OXA}-1}$. Five novel ESBL genes, $b l a_{\mathrm{TEM}-170}$ to $b l a_{\mathrm{TEM}-174}$, were detected in isolates of E. coli. These were isolated from the four different hospitals. Five novel bla $a_{\mathrm{SHV}}$ genes were identified: the $b l a_{\text {SHV-126 }}$ gene was identified in an Enterobacter isolate from hospital 2 and the genes $b l a_{\mathrm{SHV}-123}, b l a_{\mathrm{SHV}-124}, b l a_{\mathrm{SHV}-125}$ and $b l a_{\mathrm{SHV}-127}$ were detected in K. pneumoniae isolates from hospitals 2 and 4 . Of these, only bla $a_{\mathrm{SHV}-127}$ was associated with an ESBL-positive phenotype.

\section{PMQR genes and plasmid epidemiology analysis}

It was possible to segregate the predominant PMQR gene determinants based on bacterial species (Table 2). Isolates of $E$. coli and K. pneumoniae contained predominantly $a a c\left(6^{\prime}\right) I b-c r$ genes and few $q n r$ genes, whereas Enterobacter isolates contained more $q n r$ genes than $a a c\left(6^{\prime}\right) I b-c r$ genes. The distribution of resistance genes within isolates from the four hospitals followed this general pattern; however, isolates from hospital 3 contained almost exclusively $a a c\left(6^{\prime}\right) I b-c r$ genes. Isolates from hospital 4 contained the largest number of $q n r$ genes, which were more frequently detected than $a a c\left(6^{\prime}\right) I b-c r$ genes, indicating an unusual trend within this hospital with a predominance of $q n r$ rather than $a a c\left(6^{\prime}\right) I b-c r$ genes. One Enterobacter isolate contained both $q n r A$ and $q n r B$ genes and one isolate of $K$. pneumoniae was positive for both $q n r A$ and $a a c\left(6^{\prime}\right) I b$-cr genes. To our knowledge, this is the first report of an aac $\left(6^{\prime}\right) I b-c r$ gene identified in Enterobacter aerogenes. All isolates that contained an $a a c\left(6^{\prime}\right) I b-c r$ gene were intermediately resistant or resistant to ciprofloxacin; however, three qnrA-positive strains and one $q n r B$-positive strain were ciprofloxacin-susceptible. The $\operatorname{aac}\left(6^{\prime}\right) \mathrm{Ib}-\mathrm{cr}$ gene was always co-located with at least one $\beta$-lactamase gene (Table 2$)$. The most prevalent combination of $\beta$-lactamase and $a a c\left(6^{\prime}\right) I b-c r$ gene was $a a c\left(6^{\prime}\right) I b-c r$ $+b l a_{\mathrm{OXA}-1}+b l a_{\mathrm{TEM}-1}+b l a_{\mathrm{CTX}-\mathrm{M}-15}$, which was identified in four and seven isolates of $K$. pneumoniae and E. coli, respectively. This pattern of co-location was detected in isolates from hospitals 2, 3 and 4 but was most pronounced in isolates from hospital 3, with seven isolates harbouring this genotype. These genes were also reported on the pEK499 plasmid in epidemic strains of $E$. coli from the UK (Woodford et al. 2009). The second most frequently identified association of genes was $a a c\left(6^{\prime}\right) I b-c r+b l a_{\text {OXA-1 }}$

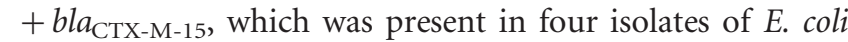
and three isolates of K. pneumoniae. The qnrA and $q n r B$ genes were detected with $b l_{\mathrm{SHV}}$ genes in isolates from hospitals 2 and 4 .

The transformation studies indicated that the $a a c\left(6^{\prime}\right) I b-c r$ gene was always associated with the $b l_{\mathrm{OXA}-1}$ gene and was frequently associated with the genes $b{ } a_{\mathrm{CTX}-\mathrm{M}-15}$ and $b l a_{\mathrm{TEM}-1}$. The presumption, in many studies to date, has been that these genes are co-transferred on the same plasmid as they are often identified in the same strains; however, in the transformation studies, in nine of the 19 strains positive for both $a a c\left(6^{\prime}\right) I b$-cr and $b l a_{\mathrm{CTX}-\mathrm{M}-15}$ genes, the $b l a_{\mathrm{CTX}-\mathrm{M}-15}$ gene was not co-transferred with $a a c\left(6^{\prime}\right)$ $I b-c r$ into competent $E$. coli cells. The nine clinical strains 
harbouring these plasmids comprised both $K$. pneumoniae and E. coli. Digested plasmids from the transformants were compared to each other and to the UK epidemic pEK499, which contains both $a a c\left(6^{\prime}\right) I b-c r$ and $b l a_{\text {CTX-M-15 }}$ genes, using BioNumerics software, as shown in Fig. 1. The only plasmid profiles that shared $100 \%$ identity were those where plasmids originated from two Enterobacter isolates (transformants $4 \mathrm{~T}$ and $5 \mathrm{~T}$ ) or from two isolates of $K$. pneumoniae (transformants 25T and 26T); all four of these plasmids were $b l a_{\mathrm{CTX}-\mathrm{M}-15}$-negative. The former of these plasmids were the only two $a a c\left(6^{\prime}\right) I b$-cr-harbouring plasmids identified in Enterobacter isolates in this study. These strains had both been isolated in the same hospital but from different patients. The banding patterns of the remaining plasmids were diverse and did not show any distinct patterns. No plasmids were, therefore, identical to plasmid pEK499; however, it is possible that genetic rearrangement has occurred, which could not have been discerned using restriction analysis.

\section{Generation of ciprofloxacin-resistant mutants from isogenic $E$. coli transformants containing aac $\left(6^{\prime}\right) / b-c r$ plasmids}

The $c r$ variant of the $a a c\left(6^{\prime}\right)-I b$ gene encodes an aminoglycoside acetyltransferase that confers reduced susceptibility to ciprofloxacin by $N$-acetylation of its piperazinyl amine (Robicsek et al., 2006). The aac(6')Ib-cr gene has been shown previously to enhance the ability of E. coli to develop ciprofloxacin resistance. The experiments of Robicsek et al. (2006) examined the development of ciprofloxacin resistance when the $a a c\left(6^{\prime}\right) \mathrm{Ib}-\mathrm{cr}$ gene was ligated into a well-characterized plasmid and transformed into E. coli. However, in clinical isolates, the aac $\left(6^{\prime}\right) I b-c r$ gene was not present on a plasmid in isolation and, as shown in this and other studies, other genes and elements are present on the same plasmid as the aac $\left(6^{\prime}\right) I b-c r$ gene. Therefore, we sought to examine the abilities of natural plasmids, which contained the $a a c\left(6^{\prime}\right) I b-c r$ gene, to enhance the selection of ciprofloxacin resistance.

Table 3. Results of mutation studies of transformants containing aac $\left(6^{\prime}\right) / b$-cr-harbouring plasmids

\begin{tabular}{|c|c|c|c|}
\hline $\begin{array}{l}\text { Competent cell/ } \\
\text { transformant parent }\end{array}$ & $\begin{array}{l}\text { MIC of ciprofloxacin } \\
\qquad\left(\mathrm{mg} \mathrm{l}^{-1}\right)\end{array}$ & $\begin{array}{l}\text { Generation number } \\
\text { required to produce } \\
\text { resistant mutants }\end{array}$ & $\begin{array}{l}\text { MIC of ciprofloxacin for } \\
\text { final generation mutants } \\
\qquad\left(\mathrm{mg} \mathrm{l}^{-1}\right)\end{array}$ \\
\hline E. coli & 0.002 & 4 & 16 \\
\hline \multicolumn{4}{|l|}{ Hospital 1} \\
\hline $9 \mathrm{~T}$ & 0.032 & 3 & 8 \\
\hline $10 \mathrm{~T}$ & 0.008 & 5 & $>16$ \\
\hline \multicolumn{4}{|l|}{ Hospital 2} \\
\hline $11 \mathrm{~T}$ & 0.008 & 4 & 8 \\
\hline $12 \mathrm{~T}$ & 0.004 & 3 & 8 \\
\hline $13 \mathrm{~T}$ & 0.008 & 5 & 16 \\
\hline $14 \mathrm{~T}$ & 0.004 & 4 & 8 \\
\hline \multicolumn{4}{|l|}{ Hospital 3} \\
\hline $15 \mathrm{~T}$ & 0.008 & 3 & 8 \\
\hline $16 \mathrm{~T}$ & 0.008 & 5 & 8 \\
\hline $17 \mathrm{~T}$ & 0.002 & 5 & 8 \\
\hline $18 \mathrm{~T}$ & 0.004 & 4 & 0.5 \\
\hline $19 \mathrm{~T}$ & 0.004 & 7 & 2 \\
\hline $20 \mathrm{~T}$ & 0.008 & 6 & 4 \\
\hline $22 \mathrm{~T}$ & 0.002 & 7 & 2 \\
\hline $23 \mathrm{~T}$ & 0.008 & 7 & 2 \\
\hline $24 \mathrm{~T}$ & 0.004 & 5 & 8 \\
\hline $25 \mathrm{~T}$ & 0.002 & 5 & 1 \\
\hline $26 \mathrm{~T}$ & 0.002 & 6 & 1 \\
\hline $27 \mathrm{~T}$ & 0.004 & 6 & 4 \\
\hline \multicolumn{4}{|l|}{ Hospital 4} \\
\hline $1 \mathrm{~T}$ & 0.008 & 5 & 16 \\
\hline $2 \mathrm{~T}$ & 0.004 & 5 & 0.25 \\
\hline $3 \mathrm{~T}$ & 0.06 & 5 & 8 \\
\hline $4 \mathrm{~T}$ & 0.016 & 4 & $>16$ \\
\hline $5 \mathrm{~T}$ & 0.032 & 4 & 8 \\
\hline $6 \mathrm{~T}$ & 0.008 & 4 & $>16$ \\
\hline $7 \mathrm{~T}$ & 0.008 & 4 & 8 \\
\hline $8 \mathrm{~T}$ & 0.004 & 5 & 0.5 \\
\hline
\end{tabular}


Highly resistant mutants were generated from 16 of the 26 transformants (Table 3). High-level ciprofloxacinresistant mutants ( $\mathrm{MIC} \geqslant 16 \mathrm{mg} \mathrm{l}^{-1}$ ) were generated from the E. coli competent cells in the fourth generation that lacked an $a a c\left(6^{\prime}\right) I b-c r$ plasmid. None of the transformants containing the $a a c\left(6^{\prime}\right) \mathrm{Ib}$-cr gene generated high-level ciprofloxacin-resistant mutants in less than four generations. High-level resistance in some mutants was achieved in four to five generations. Resistant mutants with MICs of $8 \mathrm{mg} \mathrm{l^{-1 }}$ were generated from 11 transformants, resistant mutants with MICs of 4 $\mathrm{mg} \mathrm{l}^{-1}$ were generated from two transformants and intermediately resistant mutants (MIC $2 \mathrm{mg} \mathrm{l}^{-1}$ ) were generated from three transformants. Five transformants failed to produce resistant mutants after successive generations. There was no correlation between MICs for the transformants and their ability to generate ciprofloxacin-resistant mutants. However, all of the transformants generated from isolates from hospitals 1 and 2 resulted in high-level resistant mutants with MICs $\geqslant 8 \mathrm{mg} \mathrm{l}^{-1}$. Hospital 3 contained the highest number of $\operatorname{aac}\left(6^{\prime}\right) \mathrm{Ib}$-cr-positive isolates; however, only four transformants generated mutants with MICs of $8 \mathrm{mg} \mathrm{l}^{-1}$. Six of the eight transformants obtained from isolates from hospital 4 generated mutants with $\mathrm{MICs} \geqslant 8 \mathrm{mg} \mathrm{l}^{-1}$. This suggests a difference in the abilities of isolates from the four hospitals to generate FQR mutants.

\section{Conclusions}

This study has identified a high distribution and presence of PMQR and ESBL elements in isolates from each of the hospitals. The $b l a_{\mathrm{CTX}-\mathrm{M}-15}$ and $a a c\left(6^{\prime}\right) I b$-cr genes were the predominant ESBL and PMQR genes in these isolates as a whole, but the $q n r$ genes were the predominate PMQR elements in hospital 4. There was a wide variety of plasmids carrying similar resistance genes. The qnr PMQR genes emerged most frequently in Enterobacter isolates. Novel ESBL genes were detected in isolates from each of the four hospitals and carbapenem and aminoglycoside resistance was detected in all three bacterial populations from one hospital. This highlights a potential threat to the further treatment of these infections. The epidemiological differences in the presence and colocation of PMQR and ESBL genes between the four hospitals suggest that while each hospital contains PMQR- and ESBL-positive isolates, these are not the result of a particular plasmid spreading through bacterial populations in hospitals or between patients. The results of the mutation studies highlight the differences between the plasmids isolated from the four different hospitals. This is particularly important with respect to hospital 3, which contained the largest number of $a a c\left(6^{\prime}\right) \mathrm{Ib}-\mathrm{cr}$ positive isolates but resulted in the lowest number of ciprofloxacin-resistant mutants. Thus, the presence of the aac $\left(6^{\prime}\right) I b-c r$ gene in these isolates did not necessarily result in ciprofloxacin resistance.

\section{ACKNOWLEDGEMENTS}

F. W. was supported by a post-doctoral research fellowship from the Health Research Board, Ireland. Some of the results of this study were presented at ICAAC 2008, poster C1-108. We wish to thank Dr Neil

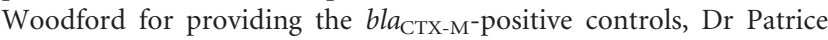
Nordmann for providing the qnr-positive controls, and all of the microbiology departments for contributing the bacterial isolates.

\section{REFERENCES}

Bonnet, R. (2004). Growing group of extended-spectrum $\beta$-lactamases: the CTX-M enzymes. Antimicrob Agents Chemother 48, 1-14.

Boyd, D. A., Tyler, S., Christianson, S., McGeer, A., Muller, M. P., Willey, B. M., Bryce, E., Gardam, M., Nordmann, P. \& Mulvey, M. R. (2004). Complete nucleotide sequence of a 92-kilobase plasmid harboring the CTX-M-15 extended-spectrum $\beta$-lactamase involved in an outbreak in long-term-care facilities in Toronto, Canada. Antimicrob Agents Chemother 48, 3758-3764.

Cantón, R., Novais, A., Valverde, A., Machado, E., Peixe, L., Baquero, F. \& Coque, T. M. (2008). Prevalence and spread of extended-spectrum $\beta$-lactamase-producing Enterobacteriaceae in Europe. Clin Microbiol Infect 14 (Suppl 1), 144-153.

CLSI (2007). Performance Standards for Antimicrobial Susceptibility Testing: Seventeenth Informational Supplement. M100-S17. Wayne, PA: Clinical and Laboratory Standards Institute.

Colom, K., Pérez, J., Alonso, R., Fernández-Aranguiz, A., Lariño, E. \& Cisterna, R. (2003). Simple and reliable multiplex PCR assay for detection of $b l a_{\mathrm{TEM}}, b l a_{\mathrm{SHV}}$ and $b l a_{\mathrm{OXA}-1}$ genes in Enterobacteriaceae. FEMS Microbiol Lett 223, 147-151.

EARS-Net (2010). Antimicrobial resistance surveillance in Europe 2009. Annual Report of the European Antimicrobial Resistance Surveillance Network (EARS-Net). Stockholm: ECDC; 2010. ISBN 978-92-9193-227-6.

Gay, K., Robicsek, A., Strahilevitz, J., Park, C. H., Jacoby, G., Barrett, T. J., Medalla, F., Chiller, T. M. \& Hooper, D. C. (2006). Plasmidmediated quinolone resistance in non-Typhi serotypes of Salmonella enterica. Clin Infect Dis 43, 297-304.

Mac Aogáin, M., Mooij, M. J., Adams, C., Clair, J. \& O’Gara, F. (2010). Emergence of extended-spectrum $\beta$-lactamase and fluoroquinolone resistance genes among Irish multidrug-resistant isolates. Diagn Microbiol Infect Dis 67, 106-109.

Munday, C. J., Boyd, D. A., Brenwald, N., Miller, M., Andrews, J. M., Wise, R., Mulvey, M. R. \& Hawkey, P. M. (2004). Molecular and kinetic comparison of the novel extended-spectrum $\beta$-lactamases CTX-M-25 and CTX-M-26. Antimicrob Agents Chemother 48, 4829-4834.

Robicsek, A., Strahilevitz, J., Jacoby, G. A., Macielag, M., Abbanat, D., Park, C. H., Bush, K. \& Hooper, D. C. (2006). Fluoroquinolonemodifying enzyme: a new adaptation of a common aminoglycoside acetyltransferase. Nat Med 12, 83-88.

Walsh, F., Willcock, J. \& Amyes, S. (2003). High-level telithromycin resistance in laboratory-generated mutants of Streptococcus pneumoniae. J Antimicrob Chemother 52, 345-353.

Woodford, N., Fagan, E. J. \& Ellington, M. J. (2006). Multiplex PCR for rapid detection of genes encoding CTX-M extended-spectrum $\beta$-lactamases. J Antimicrob Chemother 57, 154-155.

Woodford, N., Carattoli, A., Karisik, E., Underwood, A., Ellington, M. J. \& Livermore, D. M. (2009). Complete nucleotide sequences of plasmids pEK204, pEK499, and pEK516, encoding CTX-M enzymes in three major Escherichia coli lineages from the United Kingdom, all belonging to the international O25:H4-ST131 clone. Antimicrob Agents Chemother 53, 4472-4482. 